\title{
MORPHOLOGICAL VARIABILITY OF LEAVES OF SORBUS TORMINALIS (L.) CRANTZ IN POLAND
}

\author{
LESZEK BEDNORZ \\ Department of Botany, August Cieszkowski Agricultural University \\ Wojska Polskiego 71C, 60-625 Poznań, Poland \\ e-mail: lbednorz@au.poznan.pl
}

(Received: October 12, 2005. Accepted: December 22, 2005)

\begin{abstract}
This paper presents the results of the study on morphological variability of leaves of a scattered tree species Sorbus torminalis (L.) Crantz) in Poland. The leaves from short- and long shoots were collected from 17 localities widespread within the range of the species in Poland. Leaves were measured according to 15 morphological traits. The biometric data were subjected to multivariate statistical analysis in attempt to define variability between local populations. Most of the leaf traits are significantly correlated and are characterised by moderate level of variation. The average among population component of variation was $32.82 \%$ and $27.46 \%$ for leaves on short- and long shoots, respectively. The differences between sampled populations are significant, but only a weak geographical pattern of this differentiation was detected. Clinal type of variation was ascertained in two traits. Leaf traits which discriminate best the studied populations are also indicated. It was proved that leaves on short shoots differ markedly in shape and size from those of long shoots. Leaves on long shoots are steadier, but morphological trait values are less correlated. The study also confirmed the occurrence of individuals with leaves characteristic for $S$. torminalis var. perincisa Borbas et Feck and S. torminalis f. mollis Beck in a few Polish populations.
\end{abstract}

KEY WORDS: Sorbus torminalis, leaves, morphology, variability, statistical analysis.

\section{INTRODUCTION}

The genus Sorbus L. (Rosaceae: Maloideae) includes about 250 species that are widespread mainly in temperate regions of the Northern Hemisphere (Phipps et al. 1990). The same authors list 91 species occurring in Europe. Warburg and Kárpáti (1968) take into consideration only 19 species in Europe. According to a multivariate morphometric study of the genus Sorbus (Aldasoro et al. 1998) only 12 species may be easily recognized in the area.

In Poland, the following seven Sorbus species growing in the wild have been recognized: S. aria (L.) Crantz, S. aucuparia L. Emend. Hedl., S. carpatica Borbás, S. chamaemespilus (L.) Crantz, S. graeca (Spach) Kotshy, S. intermedia (Ehrh.) Pers. and S. torminalis (L.) Crantz (Mirek et al. 2002). S. torminalis (wild service tree) is a rare, scattered forest tree species with north-eastern range of distribution in Poland.

The genus Sorbus is morphologically exceedingly heterogeneous (Kovanda 1961). This differentiation refers first of all to leaves, but also fruits and flowers (Kárpáti 1960; Kovanda 1961; Gabrielian 1978; Rohrer et al. 1991, 1994; Robertson et al. 1992; Aas et al. 1994; Aldasoro et al. 1998). Leaves differ in complexity, lobing, colour, shape, venation and other features. Leaves of $S$. torminalis are simple, pinnately lobed with serrate or dentate margins and craspedodromous secondary venation (Robertson et al. 1992). Most microspecies in Sorbus were described on the basis of leaf characters (Kárpáti 1960; Düll 1961; Clapham et al. 1989). Also, a great number of varieties and forms were described in S. torminalis according to leaf characters (Kárpáti 1960; Kausch-Blecken v. Schmeling 1980; Pacyniak 1993).

Some native species of genus Sorbus were the subject of biometrical studies of leaves, but $S$. torminalis was not taken into consideration (Tyszkiewicz and Staszkiewicz 1997; Staszkiewicz 1997a, b). Hence, the main objective of this study was the analysis of morphological variability of leaves of $S$. torminalis in Poland. The second objective was to define variability between local population in relation to their geographical distribution. Because leaves on short shoots can differ markedly from those of long shoots (Kárpáti 1960; Robertson et al. 1992), these two categories were studied here separately. Their comparison makes another objective of this elaboration.

\section{MATERIAL AND METHODS}

Leaves from short- and long shoots (from 20 trees, 2 leaves of each kind from a tree) were collected from 17 localities widespread within the range of the species in Poland 


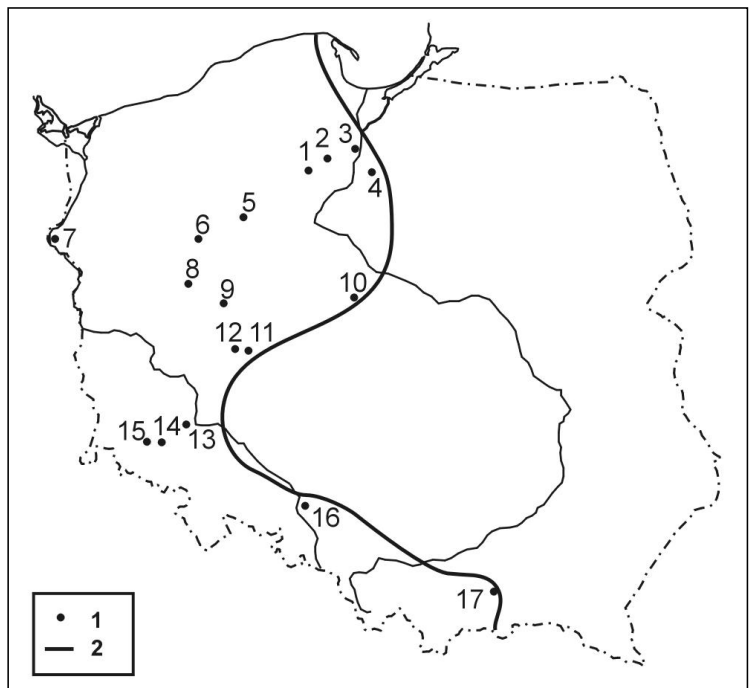

Fig. 1. Geographical distribution of sampled populations of Sorbus torminalis: 1 - localities of sampled populations (as in Table 1); 2 - north-eastern range of $S$. torminalis in Poland.

(Fig. 1, Table 1). A total of 1360 leaves from short- and long shoots were examined in respect to 13 quantitative and 2 qualitative (a and b) traits (Fig. 2):

1 - Length of petiole $(\mathrm{cm})$;

2 - Length of lamina $(\mathrm{cm})$;

3 - Max. width of lamina $(\mathrm{cm})$;

4 - Distance between 2nd and 3rd lateral vein $(\mathrm{cm})$;

5 - Number of lobes;

6 - Number of 1 st order lateral veins;

7 - Ratio of lamina length to petiole length;

8 - Ratio of lamina length to lamina width;

9 - Position of the widest part of lamina as a percentage of its length reconed from the base (\%);

$10-1 / 2$ of angle of leaf apex;

11 - Angle between base lobe vein and midrib;

12 - Depth of base lobe incision (\%);

13 - Ratio of base lobe length to base lobe width;

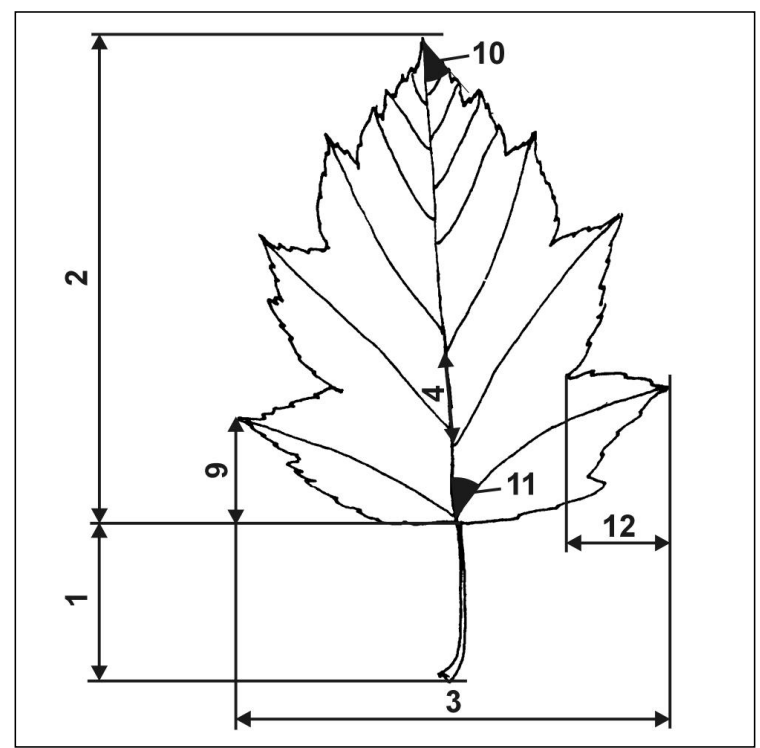

Fig. 2. Leaf measurements in Sorbus torminalis leaves. Traits 1-4 and 9-12 as on page 234 (left column).

a-Shape of leaf base ( 1 - cuneate, 2 - truncate, 3 cordate);

$\mathrm{b}$ - Presence of hairs $(1-$ absent, 2 - few, 3 - numerous).

The biometric data of 13 quantitative traits were subjected to multivariate statistical analysis using STATISTICA 6 package in order to calculate:

1. Characteristics (mean value (M), range (Min., Max.), standard deviation (SD) and coefficient of variability (CV)) of applied traits of leaves.

2. Pearson's correlation coefficients between the trait values.

3. Analysis of variance (ANOVA/MANOVA) with testing of statistical hypothesis and calculation of homogeneous groups of populations with Tukey's HSD test (Caliński and Kaczmarek 1973; Dobosz 2001).

TABLE 1. Localization of sampled populations of Sorbus torminalis.

\begin{tabular}{|c|c|c|c|c|}
\hline $\begin{array}{c}\text { Number } \\
\text { of } \\
\text { population }\end{array}$ & Population (Locality) & $\begin{array}{l}\text { Latitude } \\
\qquad \mathrm{N}\end{array}$ & $\begin{array}{c}\text { Longitude } \\
\text { E }\end{array}$ & $\begin{array}{l}\text { Altitude } \\
\text { (m) }\end{array}$ \\
\hline 2 & 'Brzęki im. Z. Czubińskiego' reserve & $53^{\circ} 39^{\prime}$ & $18^{\circ} 22^{\prime}$ & 100 \\
\hline 3 & Opalenie & $53^{\circ} 45^{\prime}$ & $18^{\circ} 48^{\prime}$ & $60-70$ \\
\hline 4 & Rogóźno & $53^{\circ} 31^{\prime}$ & $18^{\circ} 58^{\prime}$ & $60-95$ \\
\hline 7 & 'Bielinek nad Odrą' reserve & $52^{\circ} 56^{\prime}$ & $14^{\circ} 10^{\prime}$ & $40-60$ \\
\hline 8 & 'Brzęki przy Starej Gajówce' reserve & $52^{\circ} 28^{\prime}$ & $16^{\circ} 28^{\prime}$ & 100 \\
\hline 9 & Wielkopolski National Park & $52^{\circ} 16^{\prime}$ & $16^{\circ} 48^{\prime}$ & $85-100$ \\
\hline 10 & 'Kawęczyńskie Brzęki’ reserve & $52^{\circ} 24^{\prime}$ & $18^{\circ} 37^{\prime}$ & $120-130$ \\
\hline 11 & Potarzyca & $51^{\circ} 52^{\prime}$ & $17^{\circ} 24^{\prime}$ & 130 \\
\hline 12 & Piaski & $51^{\circ} 49^{\prime}$ & $17^{\circ} 12^{\prime}$ & 130 \\
\hline 17 & 'Białowodzka Góra' reserve & $49^{\circ} 41^{\prime}$ & $20^{\circ} 38^{\prime}$ & $500-550$ \\
\hline
\end{tabular}


4. Mahalanobis distances (Karoński and Caliński 1973a; Dobosz 2001).

5. Discriminant power of the traits based on analysis of discriminant function of traits (Caliński et al. 1974; Dobosz 2001).

6. Cluster analysis (agglomerative grouping) on the basis of Euclidean distances (Ward 1963; Karoński and Caliński 1973b).

Agglomerative grouping on the basis of Euclidean distances was carried out using different clustering algorithms (single linkage, complete linkage, unweighted pairgroup method using arithmetic means - UPGMA, and minimal variance-Ward method). The best separation was obtained using Ward- and UPGMA methods, and the first one is presented in this paper.

Additionally, the interaction of the trait values with geographic latitude and longitude were verified using Pearson's correlation coefficient.

Principal component analysis - PCA (Sneath and Sokal 1973) was also applied to reduce the number of variables (traits) and to ordinate $S$. torminalis leaves, but unfortunately this method did not give a satisfactory result. The first three principal components accounted for only about $57 \%$ of total variation, therefore the loss of information while reducing the multidimensional space of initial variables was to high.

\section{RESULTS}

Leaves from short- and long shoots are differentiated from each other according to size and shape traits (Tables $2,3)$. The statistical significance of this differentiation was confirmed by Student t-test. Leaves from short shoots have smaller lamina, but are set on longer petiole than leaves from long shoots. The length of petiole varies between 2.84 (Lubiechowa - long shoots) and $4.18 \mathrm{~cm}$ (Wielkopolski National Park - short shoots). The longest lamina (9.90 $\mathrm{cm}$ ) are characteristic for leaves from 'Brzęki przy Starej Gajówce' reserve. The leaves of the shortest lamina (7.09 and $7.73 \mathrm{~cm}$ for leaves from short- and long shoots respectively) occur in the population from Lubiechowa. Leaves from Lubiechowa (only long shoots) are also the narrowest ones $(7.90 \mathrm{~cm})$. In case of short shoots the ratio of lamina length to lamina width (trait 8 ) is less than 1.0 only in one population (no. 15), whereas in case of long shoots the trait

TABLE 2. Mean values of 13 traits of Sorbus torminalis leaves.

\begin{tabular}{|c|c|c|c|c|c|c|c|c|c|c|c|c|c|}
\hline \multirow{2}{*}{$\begin{array}{l}\text { No. of } \\
\text { population }\end{array}$} & \multicolumn{13}{|c|}{ Traits } \\
\hline & 1 & 2 & 3 & 4 & 5 & 6 & 7 & 8 & 9 & 10 & 11 & 12 & 13 \\
\hline & \multicolumn{13}{|c|}{ Leaves from short shoots } \\
\hline 1 & 4.16 & 8.50 & 7.82 & 1.81 & 3.28 & 7.13 & 2.11 & 1.09 & 38.03 & 30.40 & 62.83 & 50.61 & 1.29 \\
\hline 2 & 3.88 & 7.63 & 7.13 & 1.67 & 3.13 & 7.08 & 2.00 & 1.08 & 41.28 & 32.55 & 65.45 & 47.46 & 1.23 \\
\hline 3 & 3.93 & 7.95 & 7.04 & 1.65 & 3.40 & 6.83 & 2.07 & 1.14 & 46.97 & 30.05 & 59.50 & 44.31 & 1.19 \\
\hline 4 & 3.75 & 8.05 & 7.75 & 1.94 & 3.23 & 6.40 & 2.21 & 1.06 & 31.15 & 30.70 & 63.63 & 50.64 & 1.27 \\
\hline 5 & 3.77 & 7.44 & 7.25 & 1.79 & 3.13 & 6.00 & 2.03 & 1.03 & 39.36 & 29.05 & 65.98 & 50.37 & 1.35 \\
\hline 6 & 3.59 & 7.30 & 7.15 & 1.61 & 3.20 & 6.88 & 2.09 & 1.03 & 41.47 & 34.40 & 72.48 & 51.67 & 1.20 \\
\hline 7 & 3.24 & 7.42 & 6.94 & 1.52 & 3.50 & 6.70 & 2.37 & 1.09 & 34.92 & 28.85 & 70.10 & 56.23 & 1.51 \\
\hline 8 & 3.61 & 9.90 & 9.47 & 1.71 & 4.10 & 9.00 & 2.78 & 1.05 & 32.07 & 29.50 & 75.03 & 59.22 & 1.54 \\
\hline 9 & 4.18 & 8.73 & 7.05 & 1.70 & 3.40 & 6.83 & 2.11 & 1.27 & 49.75 & 30.05 & 57.65 & 33.33 & 1.02 \\
\hline 10 & 3.51 & 7.95 & 7.30 & 1.81 & 3.05 & 5.98 & 2.30 & 1.09 & 49.31 & 32.90 & 72.65 & 50.77 & 1.23 \\
\hline 11 & 3.87 & 7.94 & 7.57 & 1.52 & 3.75 & 6.88 & 2.11 & 1.06 & 35.43 & 27.43 & 63.85 & 49.55 & 1.40 \\
\hline 12 & 3.74 & 8.02 & 7.41 & 1.60 & 3.78 & 6.15 & 2.18 & 1.09 & 41.21 & 31.20 & 63.95 & 51.10 & 1.29 \\
\hline 13 & 3.77 & 7.53 & 7.05 & 1.55 & 3.28 & 7.00 & 2.04 & 1.08 & 54.50 & 34.93 & 67.35 & 34.07 & 0.90 \\
\hline 14 & 3.99 & 8.36 & 8.05 & 1.58 & 4.08 & 7.08 & 2.18 & 1.04 & 38.52 & 26.58 & 64.63 & 56.53 & 1.56 \\
\hline 15 & 3.56 & 7.09 & 7.90 & 1.24 & 3.75 & 8.25 & 2.04 & 0.91 & 43.25 & 33.50 & 69.98 & 44.28 & 1.14 \\
\hline 16 & 3.52 & 8.05 & 6.98 & 1.62 & 3.50 & 7.35 & 2.35 & 1.18 & 46.72 & 29.00 & 69.55 & 46.07 & 1.04 \\
\hline \multirow[t]{2}{*}{17} & 3.29 & 7.38 & 6.93 & 1.43 & 3.73 & 7.50 & 2.31 & 1.07 & 48.63 & 28.93 & 69.48 & 47.01 & 1.12 \\
\hline & \multicolumn{13}{|c|}{ Leaves from long shoots } \\
\hline 1 & 3.53 & 9.61 & 9.42 & 1.84 & 3.73 & 7.53 & 2.78 & 1.02 & 34.96 & 28.55 & 69.18 & 55.82 & 1.26 \\
\hline 2 & 3.57 & 8.79 & 8.85 & 1.79 & 3.53 & 7.90 & 2.49 & 1.00 & 33.87 & 31.73 & 73.33 & 52.39 & 1.21 \\
\hline 3 & 3.91 & 9.31 & 8.76 & 1.84 & 3.80 & 7.70 & 2.41 & 1.07 & 40.03 & 30.45 & 65.28 & 52.79 & 1.29 \\
\hline 4 & 3.59 & 9.50 & 10.00 & 1.99 & 3.73 & 6.98 & 2.68 & 0.96 & 27.04 & 28.45 & 68.90 & 58.53 & 1.46 \\
\hline 5 & 3.40 & 8.40 & 8.70 & 1.86 & 3.30 & 6.83 & 2.51 & 0.97 & 31.29 & 26.90 & 72.08 & 55.59 & 1.47 \\
\hline 6 & 3.42 & 8.62 & 8.98 & 1.75 & 3.55 & 7.85 & 2.58 & 0.97 & 35.08 & 31.10 & 75.15 & 56.34 & 1.25 \\
\hline 7 & 3.16 & 8.79 & 8.89 & 1.76 & 3.78 & 7.45 & 2.85 & 1.00 & 37.11 & 26.33 & 73.60 & 59.28 & 1.61 \\
\hline 8 & 3.61 & 9.90 & 9.47 & 1.71 & 4.10 & 9.00 & 2.78 & 1.05 & 32.07 & 29.50 & 75.03 & 59.22 & 1.54 \\
\hline 9 & 3.59 & 9.89 & 8.59 & 1.85 & 3.78 & 7.28 & 2.81 & 1.17 & 41.71 & 29.88 & 65.35 & 41.87 & 1.09 \\
\hline 10 & 3.35 & 9.23 & 9.07 & 1.73 & 3.48 & 6.98 & 2.79 & 1.02 & 54.08 & 31.80 & 79.50 & 59.09 & 1.38 \\
\hline 11 & 3.57 & 8.87 & 9.28 & 1.64 & 4.05 & 7.73 & 2.53 & 0.97 & 35.88 & 27.80 & 68.75 & 55.57 & 1.53 \\
\hline 12 & 3.45 & 9.09 & 8.70 & 1.73 & 4.18 & 7.28 & 2.68 & 1.05 & 32.36 & 29.33 & 68.40 & 56.66 & 1.40 \\
\hline 13 & 3.79 & 9.14 & 8.76 & 1.71 & 3.68 & 7.83 & 2.44 & 1.05 & 54.43 & 33.05 & 72.15 & 38.55 & 0.93 \\
\hline 14 & 3.87 & 9.62 & 9.68 & 1.73 & 4.80 & 8.08 & 2.53 & 1.00 & 29.11 & 25.40 & 68.40 & 61.09 & 1.58 \\
\hline 15 & 2.84 & 7.73 & 7.90 & 1.24 & 3.75 & 8.25 & 2.80 & 0.99 & 40.62 & 33.90 & 79.53 & 47.99 & 1.04 \\
\hline 16 & 3.39 & 9.57 & 8.83 & 1.86 & 3.90 & 8.03 & 2.88 & 1.10 & 41.84 & 27.28 & 73.95 & 52.69 & 1.20 \\
\hline 17 & 3.53 & 9.13 & 8.86 & 1.65 & 3.90 & 8.20 & 2.63 & 1.04 & 42.75 & 29.23 & 72.13 & 54.10 & 1.28 \\
\hline
\end{tabular}


TABLE 3. Statistic description of 13 traits (all samples) of Sorbus torminalis leaves: M - arithmetic mean, Min. - minimum, Max - maximum, SD - standard deviation, $\mathrm{CV}$ - variation coefficient.

\begin{tabular}{|c|c|c|c|c|c|c|c|c|c|c|c|c|c|}
\hline \multirow{2}{*}{ Statistics } & \multicolumn{13}{|c|}{ Traits } \\
\hline & 1 & 2 & 3 & 4 & 5 & 6 & 7 & 8 & 9 & 10 & 11 & 12 & 13 \\
\hline \multicolumn{14}{|c|}{ Leaves from short shoots } \\
\hline M & 3.72 & 7.95 & 7.46 & 1.63 & 3.49 & 7.00 & 2.19 & 1.08 & 41.92 & 30.59 & 66.71 & 48.43 & 1.25 \\
\hline Min. & 2.00 & 5.40 & 4.10 & 0.70 & 2.00 & 4.00 & 1.26 & 0.67 & 5.45 & 15.00 & 40.00 & 15.79 & 0.53 \\
\hline $\operatorname{Max}$ & 6.20 & 11.40 & 12.20 & 3.60 & 5.00 & 11.00 & 4.25 & 1.66 & 72.58 & 56.00 & 107.00 & 90.70 & 3.00 \\
\hline \multicolumn{14}{|c|}{ Leaves from long shoots } \\
\hline M & 3.50 & 9.13 & 8.98 & 1.74 & 3.82 & 7.70 & 2.66 & 1.03 & 37.90 & 29.45 & 71.80 & 53.97 & 1.32 \\
\hline Min. & 1.90 & 6.50 & 5.50 & 0.70 & 2.00 & 4.00 & 1.68 & 0.72 & 5.45 & 15.00 & 42.00 & 20.00 & 0.44 \\
\hline Max & 5.10 & 13.00 & 12.80 & 3.50 & 6.00 & 11.00 & 4.81 & 1.44 & 70.00 & 46.00 & 107.00 & 97.22 & 3.50 \\
\hline
\end{tabular}

value is less than 1.0 in five populations (nos 4, 5, 6, 11, 15). The base lobe of leaves from long shoots are more prolate, stronger deviated from the midrib, and deeper incised than those from short shoots. The mean angle between base lobe vein and midrib (trait 11) varies between 59.50 (Opalenie - short shoots) and 79.53 (Lubiechowa - long shoots). However, for a few leaves this angle reaches even 107.00. The depth of base lobe incision (trait 12) is highly variable, and in particular leaves, varies from 15.97 to 97.22\%. Comparing the populations, leaves from 'Brekinia' reserve have the least incised base lobe, whereas lea- ves from Brzęki przy Starej Gajówce' reserve have the most deeply incised base lobe. There is also a significant difference in leaf base shape between leaves from two kinds of shoots. Leaves from short shoots most often have truncate base $(40.29 \%)$, slightly rarer cordate $(32.79 \%)$ and cuneate $(26.91 \%)$. Cordate base of leaf most often $(53.68 \%)$ occurs in case of leaves from long shoots. Truncate base is characteristic for $38.68 \%$ of leaves, and only $7.65 \%$ of them have cuneate base. The percentage of leaves with different presence of hairs are similar in case of two kinds of shoots. Most of the leaves (54.41\%) have only few

TABLE 4. Correlation coefficients of 13 quantitative traits values of Sorbus torminalis leaves.

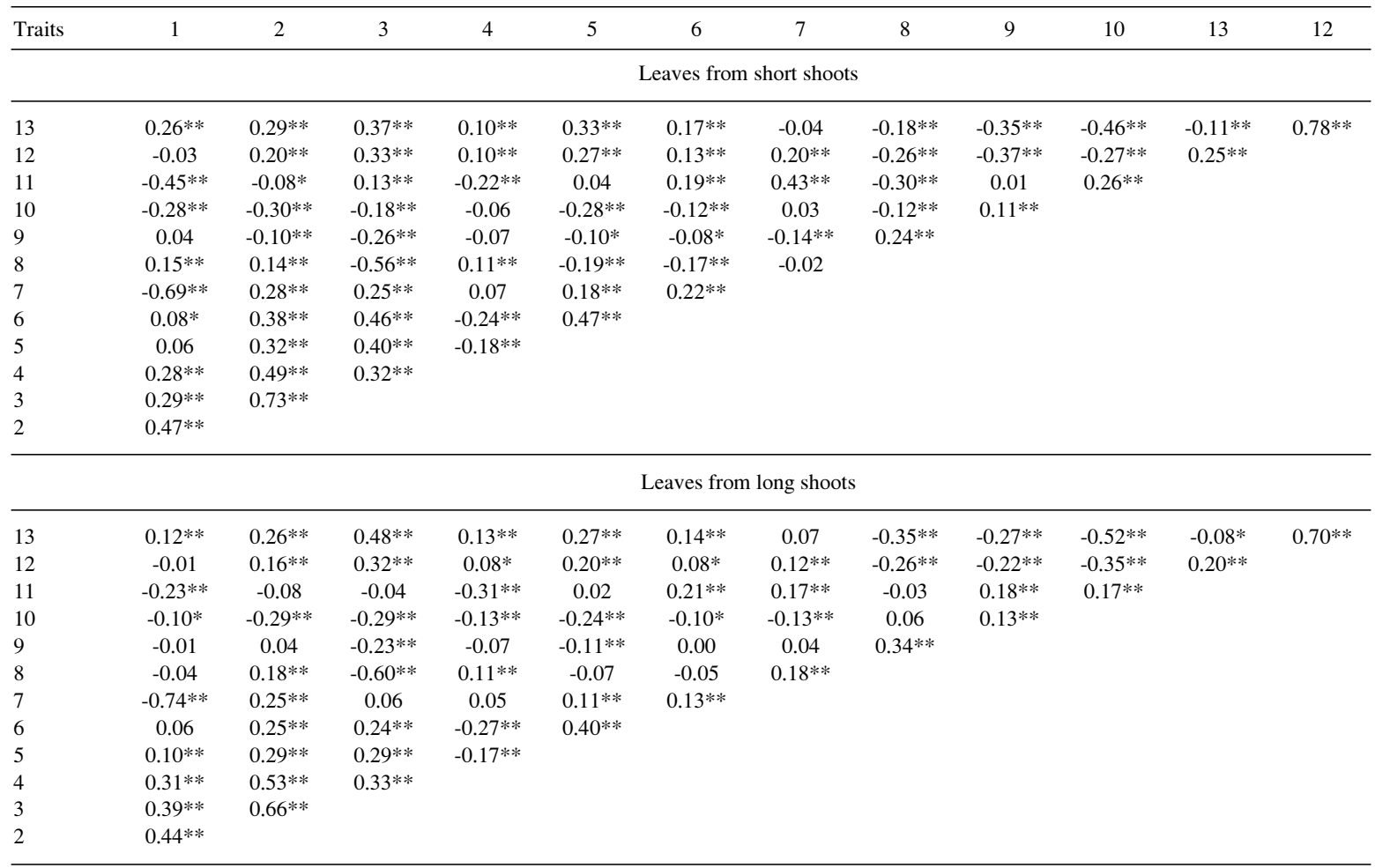

** Significant at level $\mathrm{p}=0.01$

* Significant at level $\mathrm{p}=0.05$ 


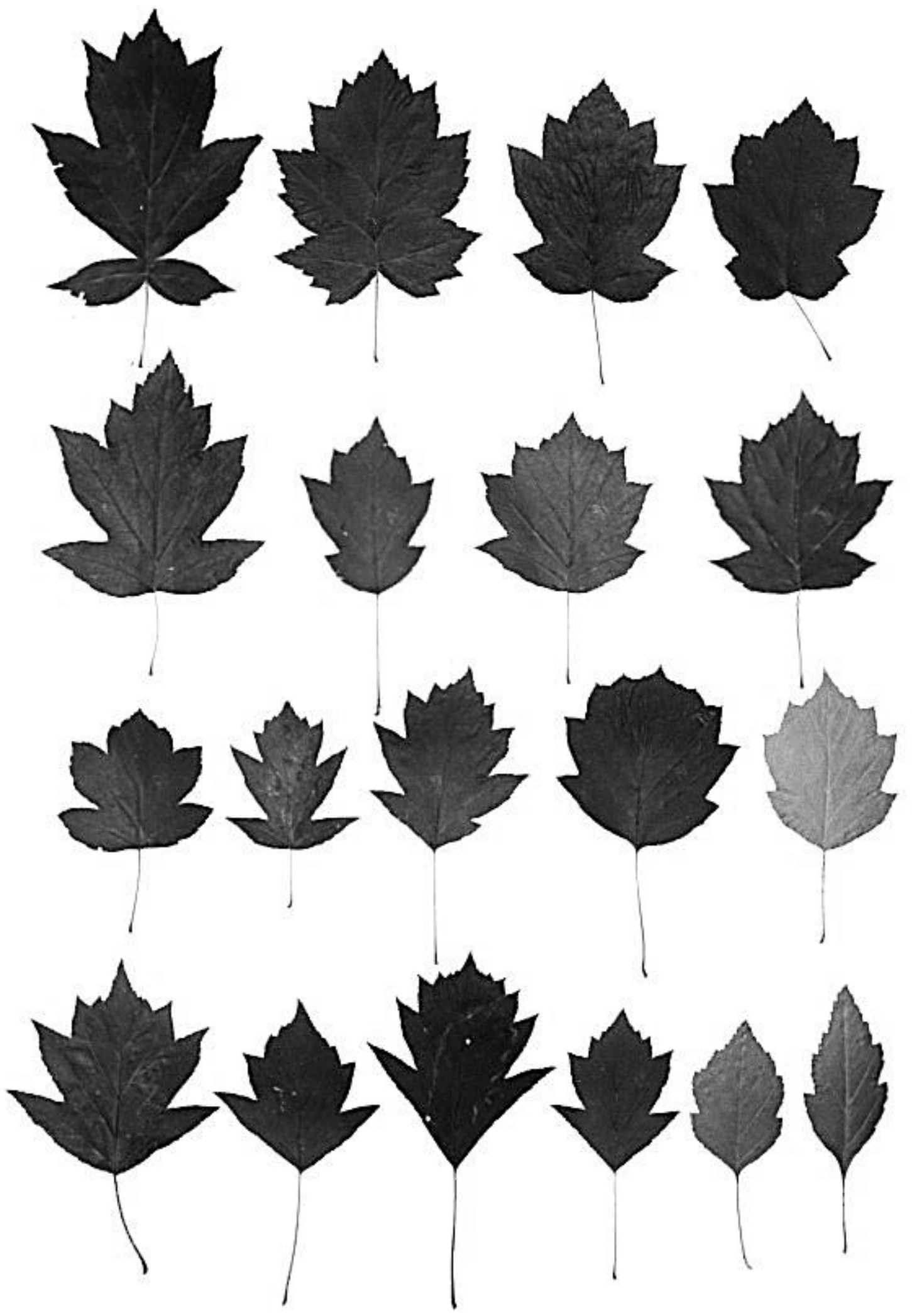

Fig. 3. Variation in shape and size of Sorbus torminalis leaves (Fot. M. Dziurla). 
hairs on their surface. Numerous hairs are present on $36.91 \%$ of leaves from short shoots and $39.41 \%$ of leaves from long shoots. Hairs are absent in case of $6.18 \%$ of leaves from short shoots and $8.68 \%$ of leaves from long shoots. The differentiation both in shape and size among $S$. torminalis leaves collected in Polish populations of the species is shown in figure 3 .

All applied quantitative traits of leaves except one, which is the position of the widest part of lamina (highly variable), are characterised by moderate level of variation (Wysocki and Lira 2003). The least variable among considered traits of leaves proved to be the ratio of lamina length to lamina width and the length of lamina (coefficient of variability $\mathrm{CV}$ for short shoots $12.68 \%$ and $14.96 \%$, respectively, and for long shoots $11.05 \%$ and $11.73 \%$ ). Definitely, the most variable trait was the position of the widest part of lamina $(\mathrm{CV}=41.64 \%$ for short shoots, and $47.68 \%$ for long shoots), (Table 3). Coefficients of variability differed not only among leaf traits but also among studied populations. The least variable are leaves from 'Brekinia' reserve, the most variable leaves occur in population of 'Bielinek nad Odrą' reserve.

Out of $76(13 \times 13)$ examined correlation coefficients (for general sample), $65(85.53 \%)$ significant correlation coefficients were found for leaves from short shoots, and 60 $(78.95 \%)$ for the leaves from long shoots (Table 4). Traits 12 and 13 (depth of base lobe of leaf incision and its shape), and traits 2 and 3 (length and width of lamina) were the most strongly positively correlated ones, whereas traits 1 and 7 (petiole length and ratio of lamina length to petiole length), were the most strongly negatively correlated ones. In case of the leaves from short shoots, size traits such as length and width of lamina and the number of 1st order lateral veins (traits $2,3,6$ ) are significantly correlated with the biggest number of leaf traits. In case of the leaves from long shoots, shape traits such as angle of leaf apex, and depth of base lobe of leaf incision and its shape (traits 10 , $12,13)$ are significantly correlated with the biggest number of other traits. For the leaves from short shoots the most frequent significant correlation coefficients were observed for the population of Wielkopolski National Park (42 $55.26 \%$ ), and the least frequent significant correlation coefficients were found for the population of Lubiechowa (17 $22.37 \%$ ). For the leaves from long shoots the most frequent significant correlation coefficients were observed for the populations of 'Kawęczyńskie Brzęki' reserve (35 - 46.05\%) and Wielkopolski National Park (34-44.74\%). On the other hand, the least frequent significant correlation coefficients were found for the population of 'Brekinia' reserve (only $11-14.47 \%$ ).

Testing the general hypothesis in multivariate analysis of variance MANOVA showed that in respect to the applied 13 traits of leaves taken together, the examined populations differed significantly between each other, as indicated by the calculated value of $F$ statistics $\left(F_{\text {calc }}=9.030\right.$ for short shoots and $\mathrm{F}_{\text {calc }}=8.60$ for long shoots; $\mathrm{F}_{0.05}=1.170$ ).

Testing of the first group of detailed hypotheses, involving differentiation among 17 populations in respect to each of the applied 13 traits of leaves, all the examined differences were found significant $\left(\mathrm{F}_{\text {calc }}>\mathrm{F}_{0.05}\right)$. The percent of variation among populations ranged from 13.45 to 72.33 (with mean 32.82) for leaves from short shoots and from 13.35 to 42.83 (with mean 27.46) for leaves from long sho- ots. Additionally, an applied Tukey's HSD test shows homogeneous groups of populations in respect to each of the applied 13 traits of leaves separately (Table 5). Populations of 'Brzęki przy Starej Gajówce' reserve, Wielkopolski National Park and Lubiechowa (nos. 8, 9 and 15) are the most divergent from other populations.

Testing the second set of detailed hypotheses examined differentiation of 17 populations arranged into 136 contrasts in MANOVA (comparisons of population pairs) in respect to all applied traits of leaves taken together. Both, for leaves from short- and long shoots, all the examined contrasts were found significant $\left(\mathrm{F}_{\text {calc }}>\mathrm{F}_{0.05}\right)$ except one - between population of 'Brzęki im. Z. Czubińskiego' reserve and population of Goraj (nos 2 and 6).

The Mahalanobis distance as a good similarity measure of two populations was also applied. The calculated Mahalanobis distances between 17 populations of wild service tree demonstrated the absence of significant differences only between the population of 'Brzęki im. Z. Czubińskiego' reserve and the population of Goraj (nos 2 and 6). All the remaining populations differ significantly between each other (Table 6). The minimum spanning trees (Fig. 4) constructed on the basis of the shortest Mahalanobis distances also indicate the divergent character of populations of Wielkopolski National Park (no 9) and Lubiechowa (no 15 ), and in respect of short shoots, also the population of 'Brzęki przy Starej Gajówce' reserve (no 8). Leaves from long shoots collected in 'Białowodzka Góra' reserve are to the most extent similar to the leaves from other Polish populations and therefore they are the most representative for Poland.

The analysis of discriminant function was applied to decide which of leaf traits (variables) discriminate best the 17 analysed populations of $S$. torminalis. This analysis showed that three traits: the number of 1 st order lateral veins, the number of lobes, and the depth of base lobe incision (traits 6,5 and 12 , respectively), had the highest contribution to discrimination of the populations (Table 7). The petiole length (trait 1) and the related to it ratio of lamina length to petiole length (trait 7) demonstrated the lowest discriminant power among all applied traits of leaves (showed the highest values of Partial Lambda Wilksa and p-level).

Dendrograms showing relations between investigated populations (in respect to all traits together), divide them into two groups partly connected with their geographic distribution (Fig. 5). Most populations from north-western Poland (Pomerania and Great Poland) landed in one, bigger group. The population from Jawor (Pogórze Sudeckie) and partly the population of 'Kamień Śląski' reserve refer to them. The remaining populations from southern Poland together with two populations from Great Poland (Wielkopolski National Park and 'Kawęczyńskie Brzęki' reserve) make the second group.

The interaction of values of particular traits with geographic latitude and longitude is very weak. In case of leaves on short shoots, trait 4 (distance between 2nd and 3rd lateral vein) is positively (at $\mathrm{p}=0.01$ ), while trait 5 (number of lobes) is negatively (at $\mathrm{p}=0.05$ ) correlated with geographic latitude. For leaves on long shoots only one trait - distance between $2^{\text {nd }}$ and $3^{\text {rd }}$ lateral vein) is positively, significantly (at $\mathrm{p}=0.05$ ) correlated with geographic latitude. 
TABLE 5. The results of analysis of variance (ANOVA) defining differentiation of 17 Sorbus torminalis populations in respect to 13 traits of leaves from short- and long shoots (separately) together with homogeneous groups of populations set on the basis of Tukey's HSD test: $\mathrm{S}_{\mathrm{A}}^{2}$ [\%] - percent variation among populations; $\mathrm{F}_{0.05}=1.659$.

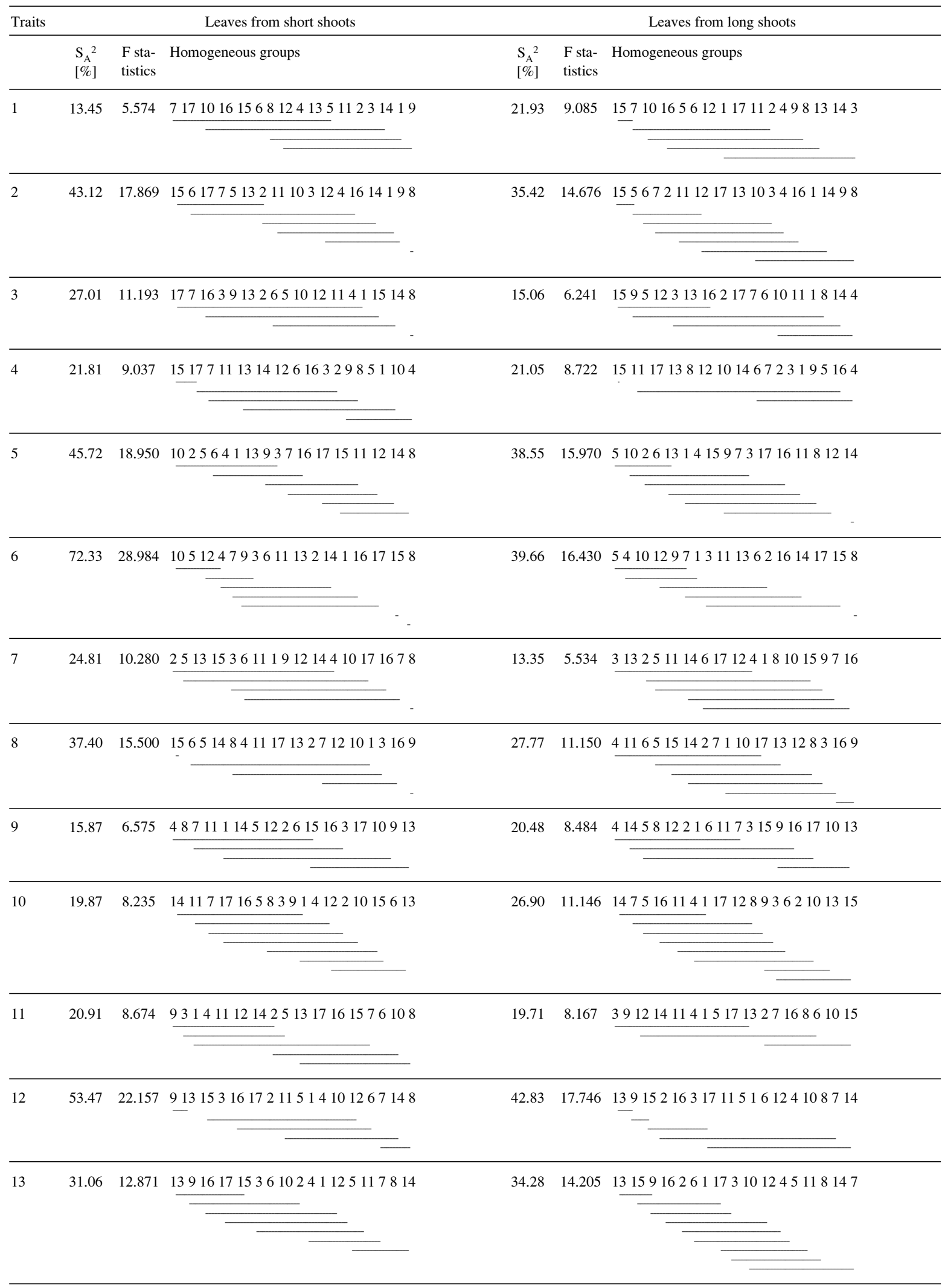




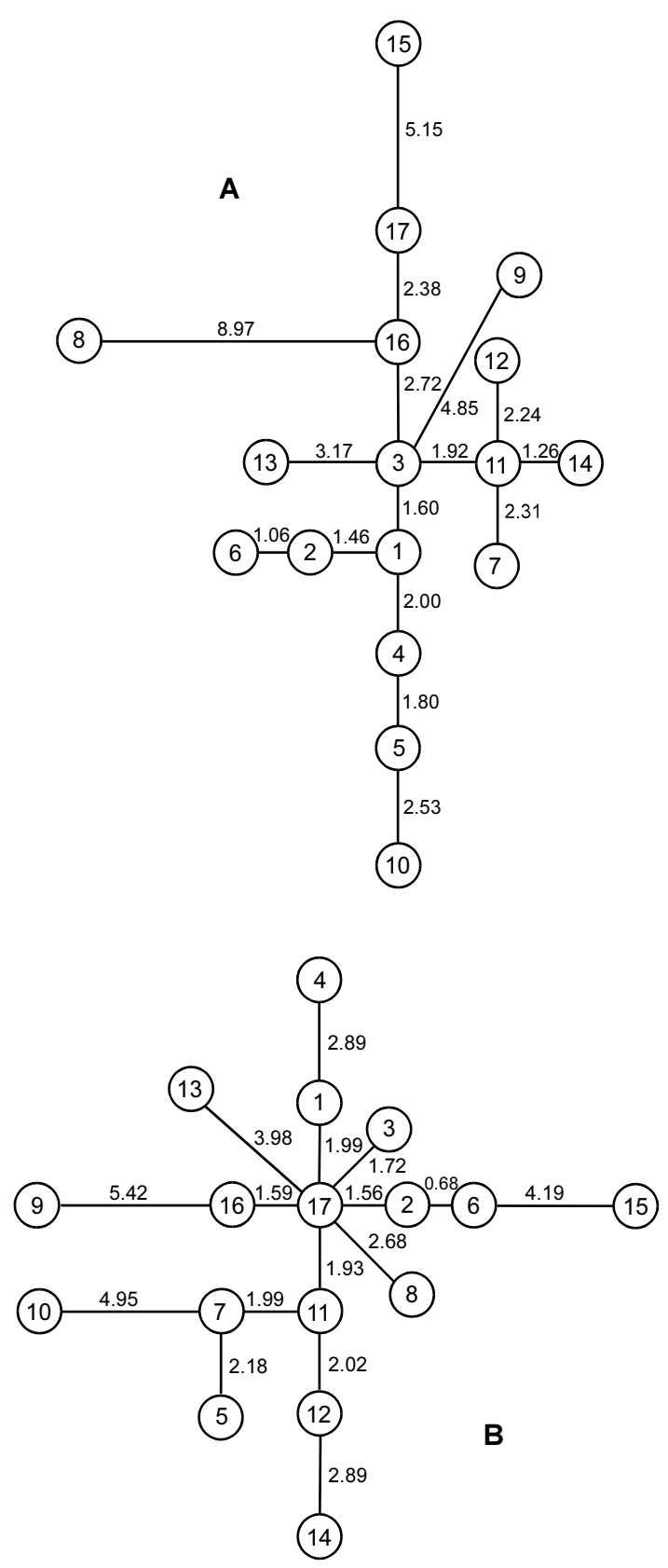

Fig. 4. Minimum spanning trees of 17 Sorbus torminalis populations for 13 traits of leaves from short- (A) and long (B) shoots constructed on the basis of Mahalanobis distances.

\section{DISCUSSION}

Leaves on short shoots are most often measured in studies on morphological variability of leaves in different tree species, because they are considered to be more steady. This elaboration reveals, that in case of $S$. torminalis, leaves on long shoots are steadier as compared with those on short shoots. The same result was obtained for $S$. intermedia leaves (Staszkiewicz 1997b). On the other hand, this study shows that morphological trait values are less correlated, and the average among population component of va-
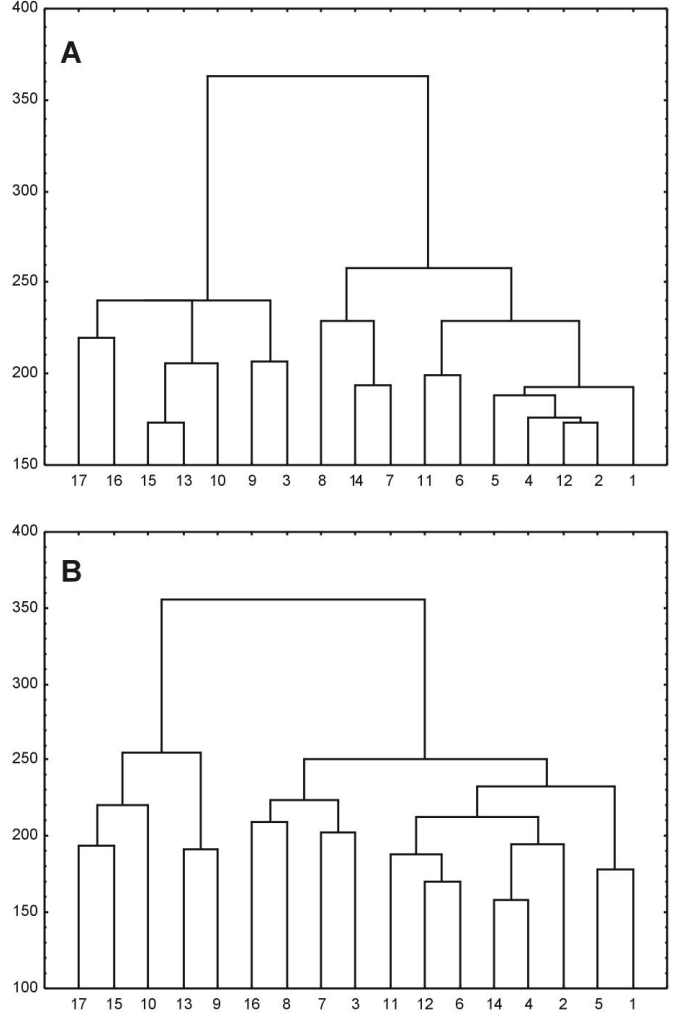

Fig. 5. Dendrograms of 17 Sorbus torminalis populations constructed on the basis of the shortest Euclidean distances (calculated on the basis of 13 traits of leaves from short- (A) and long (B) shoots).

riation is lower in case of leaves on long shoots. These two facts would indicate that, after all, leaves on short shoots better characterise interpopulational variability in S. torminalis.

This work also reveals that leaves on short shoots differ markedly in relation to morphological traits, from those of long shoots. Hence, to show the full range of variation, both leaves on short- and long shoots should be taken into consideration. Already, Kárpáti (1960) the great expert of S. torminalis, has pointed out that even within the same individual, leaves may vary considerably between different kinds of shoots and according to their position in the tree crown.

According to Robertson and others (1992), as a general rule in subfamily Maloideae, the leaves on long shoots tend to be larger and have sharper, more distinct teeth and/or deeper lobing than those on short shoots. The present study shows that also in S. torminalis leaves on long shoots are larger, and the base lobe is deeper, in comparison with those on short shoots.

Substantial morphological differentiation among $S$. torminalis populations according to the leaf features was detected. Significant differences by analysis of variance and other applied statistical methods arise probably from geographical disjoint of its localities. S. torminalis is a typical scattered tree species with discontinuous range in Poland.

The detected considerable morphological variation in $S$. torminalis leaves, collected from 17 localities widespread within the range of the species in Poland, showed a relati- 
TABLE 6. Mahalanobis distances between 17 Sorbus torminalis populations calculated on the basis of 13 traits of leaves.

\begin{tabular}{|c|c|c|c|c|c|c|c|c|c|c|c|c|c|c|c|c|}
\hline Population & 1 & 2 & 3 & 4 & 5 & 6 & 7 & 8 & 9 & 10 & 11 & 12 & 13 & 14 & 15 & 16 \\
\hline \multicolumn{17}{|c|}{ Leaves from short shoots } \\
\hline 17 & $4.928 * *$ & $4.205^{* * *}$ & $3.171 * *$ & $6.588^{* * *}$ & $6.559^{* *}$ & $4.174 * *$ & $4.321^{* *}$ & $10.431^{* * *}$ & $11.510^{* * *}$ & $8.198^{* *}$ & $3.486^{* *}$ & $6.769 * *$ & $5.135^{* *}$ & $4.561^{* *}$ & $5.145^{* *}$ & $2.388^{* * *}$ \\
\hline 16 & $3.786 * *$ & $3.832 * *$ & $2.716^{* *}$ & $4.798 * *$ & $6.859 * *$ & $4.782 * *$ & $5.131 * *$ & $8.965^{* * *}$ & $6.407 * *$ & $6.294 * *$ & $4.428 * *$ & $6.572 * *$ & $5.756^{* *}$ & $6.300 * *$ & $9.411 * *$ & \\
\hline 15 & $9.314 * *$ & $6.383 * *$ & $8.485 * *$ & $11.260 * *$ & $11.817 * *$ & $6.334 * *$ & $11.116 * *$ & $14.232^{* * *}$ & $17.732 * *$ & $15.254 * *$ & $8.334 * *$ & $13.547 * *$ & $6.141^{* *}$ & $10.457^{* * *}$ & & \\
\hline 14 & $4.633 * *$ & $6.724 * *$ & $3.915 * *$ & $5.415^{* * *}$ & $5.549 * *$ & $6.497 * *$ & $3.249 * *$ & $9.735^{* *}$ & $11.741 * *$ & $7.236 * *$ & $1.256^{*}$ & $2.343 * *$ & $9.644 * *$ & & & \\
\hline 13 & $5.467 * *$ & $3.181 * *$ & $3.167 * *$ & $6.939 * *$ & $6.552 * *$ & $4.698 * *$ & $8.769 * *$ & $15.709^{* * *}$ & $6.546^{* *}$ & $6.752 * *$ & $5.789 * *$ & $8.316 * *$ & & & & \\
\hline 12 & $5.066 * *$ & $6.676 * *$ & $3.294 * *$ & 4.470 ** & $5.029 * *$ & $6.161 * *$ & $4.317^{* *}$ & $13.621^{* * *}$ & $8.820^{* * *}$ & $4.369 * *$ & $2.238 * *$ & & & & & \\
\hline 11 & $3.393 * *$ & $3.944 * *$ & $1.924 * *$ & $3.418^{* * *}$ & $3.200 * *$ & $4.729 * *$ & $2.307 * *$ & $10.893^{* * *}$ & $7.714 * *$ & $5.507 * *$ & & & & & & \\
\hline 10 & $4.385^{* *}$ & $4.200 * *$ & $4.337 * *$ & $3.338 * *$ & $2.533^{* *}$ & $3.591 * *$ & $4.097 * *$ & $14.514^{* * *}$ & $9.992 * *$ & & & & & & & \\
\hline 9 & $8.585^{* *}$ & $8.817 * *$ & $4.847 * *$ & $9.263^{* *}$ & $11.640 * *$ & $13.209 * *$ & $11.890 * *$ & $16.333^{* * *}$ & & & & & & & & \\
\hline 8 & $9.231 * *$ & $11.797 * *$ & $11.653 * *$ & $12.853 * *$ & $17.721 * *$ & $12.546 * *$ & $11.171 * *$ & & & & & & & & & \\
\hline 7 & $4.846^{* *}$ & $4.338 * *$ & $4.062 * *$ & $3.820^{* *}$ & $3.089^{* *}$ & $4.009 * *$ & & & & & & & & & & \\
\hline 6 & $2.580^{* *}$ & 1.062 & $3.631 * *$ & $3.122 * *$ & $3.124 * *$ & & & & & & & & & & & \\
\hline 5 & $3.831^{* *}$ & $3.062 * *$ & $3.604 * *$ & $1.802 * *$ & & & & & & & & & & & & \\
\hline 4 & $2.001 * *$ & $2.584 * *$ & $2.902 * *$ & & & & & & & & & & & & & \\
\hline 3 & $1.604 * *$ & $1.850^{* * *}$ & & & & & & & & & & & & & & \\
\hline 2 & $1.464 * *$ & & & & & & & & & & & & & & & \\
\hline \multicolumn{17}{|c|}{ Leaves from long shoots } \\
\hline 17 & $1.993^{* *}$ & $1.561 * *$ & $1.721 * *$ & $5.678^{* * *}$ & $6.136^{* *}$ & $2.051 * *$ & $3.833^{* *}$ & $2.678^{* * *}$ & $7.587^{* *}$ & $5.750^{* * *}$ & $1.931^{* *}$ & $2.930 * *$ & $3.980^{* *}$ & $5.158^{* * *}$ & $4.913^{* *}$ & $1.593^{* *}$ \\
\hline 16 & $2.224 * *$ & $3.292 * *$ & $3.327 * *$ & $5.118^{* *}$ & $6.766^{* *}$ & $3.861 * *$ & $4.030^{* * *}$ & $4.217 * *$ & $5.418^{* *}$ & $7.208^{* * *}$ & $4.034 * *$ & $3.762^{* * *}$ & $5.609^{* *}$ & $6.260^{* * *}$ & $8.178^{* *}$ & \\
\hline 15 & $9.125 * *$ & 4.668 ** & $9.453 * *$ & $13.498^{* * *}$ & $10.057 * *$ & $4.194 * *$ & $7.940 * *$ & $9.009 * *$ & $16.044 * *$ & $9.740 * *$ & $7.087 * *$ & $9.510^{* *}$ & $6.934^{* *}$ & $14.665^{* *}$ & & \\
\hline 14 & $5.876 * *$ & $8.754 * *$ & $5.073 * *$ & $7.534 * *$ & $11.263 * *$ & $8.938^{* *}$ & $7.491 * *$ & 6.970 ** & $12.206 * *$ & $13.233^{* *}$ & $3.901 * *$ & $2.892 * *$ & $12.618 * *$ & & & \\
\hline 13 & $6.425 * *$ & $4.371 * *$ & $4.782 * *$ & $10.614 * *$ & $10.208 * *$ & 6.356 ** & $9.861 * *$ & $8.751^{* * *}$ & $7.097 * *$ & $8.187^{* * *}$ & $6.419^{* *}$ & $8.238^{* * *}$ & & & & \\
\hline 12 & $2.610^{* *}$ & $4.870^{* * *}$ & $2.474 * *$ & $3.853 * *$ & $6.198 * *$ & $5.463 * *$ & $3.692 * *$ & $5.598^{* *}$ & $6.428 * *$ & $6.255^{* *}$ & $2.022^{* *}$ & & & & & \\
\hline 11 & 3.430 ** & $3.217 * *$ & $2.806 * *$ & $3.564 * *$ & $4.068^{* *}$ & $3.357^{* * *}$ & $1.990^{* *}$ & $5.374 * *$ & $8.566^{* *}$ & 6.040 ** & & & & & & \\
\hline 10 & $4.991 * *$ & $6.238^{* * *}$ & $7.154 * *$ & $5.918^{* * *}$ & $6.369^{* *}$ & $5.708^{* *}$ & $4.949 * *$ & $9.683 * *$ & $11.161^{* *}$ & & & & & & & \\
\hline 9 & $6.553 * *$ & $10.062 * *$ & $5.552 * *$ & $8.163 * *$ & $13.581 * *$ & $12.735^{* *}$ & $10.580^{* * *}$ & $10.121^{* * *}$ & & & & & & & & \\
\hline 8 & $5.103 * *$ & $4.201 * *$ & $4.399 * *$ & $9.188 * *$ & $11.203 * *$ & $5.729^{* * *}$ & $7.254 * *$ & & & & & & & & & \\
\hline 7 & $4.635^{* * *}$ & $4.392 * *$ & $5.728 * *$ & $3.878 * *$ & $2.182^{* *}$ & $3.675 * *$ & & & & & & & & & & \\
\hline 6 & $3.369 * *$ & 0.677 & $4.234 * *$ & $4.838^{* *}$ & $4.097 * *$ & & & & & & & & & & & \\
\hline 5 & $5.730^{\text {*** }}$ & $4.224 * *$ & $7.480^{* * *}$ & $4.870^{* * *}$ & & & & & & & & & & & & \\
\hline 4 & $2.887 * *$ & $5.224 * *$ & $5.208^{* * *}$ & & & & & & & & & & & & & \\
\hline 3 & $2.660^{* * *}$ & $3.030^{* * *}$ & & & & & & & & & & & & & & \\
\hline 2 & $3.158^{* * *}$ & & & & & & & & & & & & & & & \\
\hline
\end{tabular}


TABLE 7. The discriminant power of 13 traits of leaves collected from 17 Sorbus torminalis populations.

\begin{tabular}{|c|c|c|c|c|c|c|c|c|}
\hline Traits & \multicolumn{4}{|c|}{ Leaves from short shoots } & \multicolumn{4}{|c|}{ Leaves from long shoots } \\
\hline 1 & 0.083 & 0.959 & 0.038 & 0.046 & 0.091 & 0.972 & 0.280 & 0.039 \\
\hline 2 & 0.084 & 0.945 & 0.002 & 0.025 & 0.096 & 0.926 & 0.000 & 0.020 \\
\hline 3 & 0.086 & 0.929 & 0.000 & 0.019 & 0.099 & 0.898 & 0.000 & 0.015 \\
\hline 6 & 0.121 & 0.659 & 0.000 & 0.592 & 0.122 & 0.727 & 0.000 & 0.670 \\
\hline 7 & 0.082 & 0.969 & 0.186 & 0.060 & 0.091 & 0.972 & 0.288 & 0.042 \\
\hline 8 & 0.088 & 0.909 & 0.000 & 0.043 & 0.100 & 0.889 & 0.000 & 0.029 \\
\hline 9 & 0.084 & 0.948 & 0.004 & 0.839 & 0.100 & 0.887 & 0.000 & 0.848 \\
\hline 10 & 0.089 & 0.897 & 0.000 & 0.717 & 0.102 & 0.868 & 0.000 & 0.733 \\
\hline 11 & 0.086 & 0.927 & 0.000 & 0.557 & 0.100 & 0.887 & 0.000 & 0.725 \\
\hline
\end{tabular}

vely weak geographical structure. This fact may be explained partly by seed dispersal mode in S. torminalis, which is predominantly by birds also on long distances during their migration in autumn (Demesure et al. 2000). Also postglacial migration of the species could have strongly affected the current level of differentiation. There are a few most possible routes of $S$. torminalis migration to Poland: from the south, through Morawska Gate and along Dunajec and Poprad River valleys, and, from the west, along Torun Eberswald proglacial stream valley (Pawłowski 1925; Szafer 1927; Czubiński 1950). However, the origin of particular wild service tree populations is unknown. From several analysed leaf traits only two: distance between 2 nd and 3rd lateral vein (trait 4) and number of lobes (trait 5) change continuously along latitudinal gradient, and thus variation in these particular traits represents a clinal type of variation. The farther north population is located, S. torminalis leaves have less lobes, and distance between 2nd and 3rd lateral vein increases. No significant interaction of values of particular traits with geographic longitude was noted. Traits with clinal variation can be useful in explaining the postglacial migration of the species (Stebbins 1958), but unfortunately, there are no studies on morphological variability of $S$. torminalis on a large geographical scale.

It is also well known that leaf form in most Sorbus species varies according to ecological conditions (Gabrielian 1978). In case of $S$. torminalis its habitat niche range is relatively wide, so that ecological factors can markedly influence leaf morphology.

Similarly, a weak geographical structure of variation was detected for the leaves of S. aucuparia in Poland (Tyszkiewicz and Staszkiewicz 1997).

The analysis of discriminant function showed that three traits: number of 1st order lateral veins, number of lobes, and depth of base lobe incision (traits 6, 5 and 12, respectively), had the highest contribution to discrimination of the populations. The significance of these traits in differentiation of studied populations was confirmed by high portion of among population component of total variation for these traits.

It is known that leaves of $S$. torminalis are very variable and a number of varieties and forms were described within the species according to leaf characters (Kárpáti 1960;
Kausch-Blecken v. Schmeling 1980). In Poland, some varieties and forms distinguished on the basis of leaf characters were noted before (Goetz 1928; Kobenza 1955; Pacyniak 1993; Bednorz 2000). This morphometric study of $S$. torminalis leaves confirmed the occurence of individuals with leaves characteristic for S. torminalis var. perincisa Borbas et Feck ('Brzęki przy Starej Gajówce' reserve, 'Kawęczyńskie Brzęki' reserve, Potarzyca), and S. torminalis f. mollis Beck (Wielkopolski National Park).

Kárpáti (1960) and some other authors point out that one should be very careful and critical in admitting to great natural variability of leaves the taxonomical value. According to Aldasoro and others (1998), though in S. torminalis leaf shape is very variable, no taxa can be segregated from within it.

\section{ACKNOWLEDGEMENTS}

I would like to thank Dr Romana Głowicka for help with carrying out the statistical computations and Anna Mularski for linguistic verification of the manuscript.

\section{LITERATURE CITED}

AAS G., MAIER J., BALTISBERGER M., METZGER S. 1994. Morphology, isozyme variation, cytology, and reproduction of hybrids between Sorbus aria (L.) Crantz and Sorbus torminalis (L.) Crantz. Botanica Helvetica 104: 195-214.

ALDASORO J.J., AEDO C., NAVARO C., GARMENDIA F.M. 1998. The Genus Sorbus (Maloideae, Rosaceae) in Europe and in North Africa: Morphological Analysis and Systematics. Systematic Botany 23, 2: 189-212.

BEDNORZ L. 2000. Zmienność morfologiczna jarzẹbu brekinii [Sorbus torminalis (L.) Crantz] w Wielkopolskim Parku Narodowym. Rocz. Dendrol. 48: 35-43. (in Polish with English summary).

CALIŃSKI T., KACZMAREK Z. 1973. Metody kompleksowej analizy doświadczenia wielocechowego. Trzecie Colloquium Metodologiczne z Agro-Biometrii. PAN Warszawa (in Polish)

CALIŃSKI T., DYCZKOWSKI A., KACZMAREK Z. 1974. The selection of variables for the analysis of multivariate experimental date. Rocz. AR Pozn. Algor. Biometr. Statyst. 28: 117 142. (in Polish with English summary) 
CLAPHAM A.R., TUTIN T.G., MOORE D.M. 1989. Flora of the British Isles, third ediction. Cambridge Univ. Press, Cambridge.

CZUBIŃSKI Z. 1950. Zagadnienia geobotaniczne Pomorza. Bad. Fizjogr. Pol. Zach. 2, 4: 439-658. (in Polish with English summary)

DEMESURE B., LEGUERROUÉ B., LUCCHI G., PRAT D., PETIT R.J. 2000. Genetic variability of a scattered temperate forest tree: Sorbus torminalis L. (Crantz). Ann. For. Sci. 57, 63-71.

DOBOSZ M. 2001. Wspomagana komputerowo statystyczna analiza wyników badań. Akademicka Oficyna Wydawnicza EXIT, Warszawa. pp. 452. (in Polish)

DÜLL R. 1961. Die Sorbus-Arten und ihre bastarden in Bayern und Thüringen. Berichte der Bayerischen Botanischen Gesellschaft zur Erforschung der Heimischen Flora 34: 11-65.

GABRIELIAN E. 1978. The genus Sorbus in Western Asia and the Himalayas. Izdatielstwo Akademii Nauk Armianskoj SSR, Erevan. (in Russian with English summary)

GOETZ J. 1928. Kilka notatek, dotyczacych brzęu (Sorbus torminalis Crantz) w Polsce Zachodniej. Przegląd Leśniczy 4: 135-143. (in Polish)

KAROŃSKI M., CALIŃSKI T. 1973a. Grouping of multivariate normal populations on the basis of Mahalanobis distances. Rocz. AR Pozn. Agor. Biometr. Statyst. 16: 105-109. (in Polish with English summary)

KAROŃSKI M., CALIŃSKI T. 1973b. Grouping in multivariate populations on the basis of Euclidean distances. Rocz. AR Pozn. Agor. Biometr. Statyst. 17: 117-129. (in Polish with English summary)

KAUSCH-BLECKEN V., SCHMELING W. 1980. Die Elsbeere. Aus dem Walde 33: 1-183.

KÁRPÁTI Z. 1960. Die Sorbus - Arten Ungarns und der angrenzenden Gebiete. Feddes Repert. 62: 71-331.

KOBENDZA R. 1955. Podrodzina: Pomoideae, Jabłkowe. In: W. Szafer, B. Pawłowski (ed.), Flora polska. Rośliny naczyniowe Polski i Ziem Ościennych. t. 7. pp. 242-269. PWN Warszawa (in Polish)

KOVANDA M. 1961. Flower and Fruit Morphology of Sorbus in Correlation to the Taxonomy of the Genus. Preslia 33: 1-16.

MIREK Z., PIĘKOŚ-MIRKOWA H., ZAJĄC A., ZAJĄC M. 2002. Flowering plants and pteriodophytes of Poland. A checklist. Krytyczna lista roślin naczyniowych Polski. W. Szafer Institute of Botany, Polish Academy of Sciences, Kraków. (in Polish and English)

PACYNIAK C. 1993. Nowe formy jarzębu brekinii (Sorbus torminalis Crantz) i niektórych innych gatunków drzew. Pr.
Kom. Nauk Roln. Kom. Nauk Leśn. PTPN 76: 99-105. (in Polish with English summary)

PAWŁOWSKI B. 1925. Geobotaniczne stosunki Sądecczyzny. Prace Monogr. Kom. Fizjogr. PAU 1: 1-342. (in Polish)

PHIPPS J.B., ROBERTSON K.R., SMITH P.G., ROHRER J.R. 1990. A checklist of the subfamily Maloideae (Rosaceae). Can. J. Bot. 68: 2209-2269.

ROBERTSON K.R., PHIPPS J.B., ROHRER J.R. 1992. Summary of leaves in the genera of Maloideae (Rosaceae). Ann. Missouri Bot. Gard. 79, 1: 81-94.

ROHRER J.R., ROBERTSON K.R., PHIPPS J.B. 1991. Variation in structure among fruits of Maloideae (Rosaceae). Am. J. Bot. 78 (12): 574-581.

ROHRER J.R., ROBERTSON K.R., PHIPPS J.B. 1994. Floral morphology of Maloideae (Rosaceae) and its systematic relevance. Am. J. Bot. 81: 1617-1635.

SNEATH P.H., SOKAL R.R. 1973. Numerical taxonomy. Freeman Co. San Francisco.

STASZKIEWICZ J. 1997a. Zmienność liści jarząbu mącznego Sorbus aria, jarząbu greckiego - S. graeca, jarząbu pośredniego - S. austriaca (Rosaceae) i form pośrednich. Fragm. Flor. Geobot. Ser. Polonica Suppl. 2: 109-118. (in Polish with English summary)

STASZKIEWICZ J. 1997b. Zmienność liści jarząbu szwedzkiego - Sorbus intermedia (Rosaceae). Fragm. Flor. Geobot. Ser. Polonica Suppl. 2: 119-124. (in Polish with English summary)

STEBBINS G.L. 1958. Zmienność i ewolucja roślin. PWN, Warszawa. (in Polish)

SZAFER W. 1927. Znaczenie Bramy Morawskiej jako drogi migracji roślin z południa do Polski. Compt. Rend. du $1^{\text {er }}$ Congrès des Gèographes et Etnographes Slaves, 1924 Prague. (in Polish)

TYSZKIEWICZ M., STASZKIEWICZ J. 1997. Zmienność liści jarzębiny pospolitej - Sorbus aucuparia (Rosaceae). Fragm. Flor. Geobot. Ser. Polonica Suppl. 2: 99-108. (in Polish with English summary)

WARBURG E.F., KÁRPÁTI Z. 1968. Sorbus L. In: T.G. Tutin, V.H. Heywood, N.A. Burges, D.H. Valentine, S.M. Walters, D.A. Webb (ed.), Flora Europaea 2, pp. 67-71. Univ. Press, Cambridge.

WARD J.H. 1963. Hierarchical grouping to optimize an objective function. J. Am. Statist. Assoc. 58: 236-244.

WYSOCKI F., LIRA J. 2003. Statystyka opisowa. Wydawnictwo Akademii Rolniczej im. Augusta Cieszkowskiego w Poznaniu. (in Polish) 